\title{
INTRODUCTION
}

\author{
Raymond Fielding
}

Every now and then, some part of the great Sargasso Sea of scholarship boils over with the publication of a really basic new research study. For an historian, the experience is both exciting and painful. It is exciting in that it opens new routes along which the scholar can travel in his exploration of the field. It is painful because it requires the same historian to reexamine the resources upon which his investigations have previously depended, and to navigate along entirely different courses than those for which he had prepared himself. The more fundamental the new work, the more exciting the vistas which are revealed. The more all-embracing its implications, the more painful the scholarly clean-up job involved. The most commonplace assumptions have to be revised, some conclusions qualified, certain speculations abandoned, and a lot of textbooks re-written.

The field of motion picture history is only a few decades old, and it doesn't take much in the way of basic research to require still another in a long series of agonizing reappraisals of all the muddled work that has gone before. This new work, this index of Mr. Niver's, is going to cause everyone, everywhere, a great deal of trouble. It is exhaustive, detailed, authoritative, and basic, and its data contradict a great many of the assumptions upon which we have based our early film histories.

On the face of it, the book looks harmless enough. It is an index of films produced throughout the world between 1894 and 1912, paper-positive prints of which were deposited with the Library of Congress during those years for copyright purposes. Altogether, some 3,000 titles are listed here, representing more than two million linear feet of film-incunabula of the cinema.

By all rights, these 3,000 films should have been lost to historians entirely. Paper positives were never meant to be pro- 
jected. More important, their life span is limited. In time, they shrink, crumble, and lose whatever dimensional integrity they once possessed. Happily, beginning in 1953, Kemp Niver went to work reprinting these precious early films onto modern emulsions, using unique apparatus of his own design. He finally finished in 1965. For this achievement, he has already been honored on many occasions, most notably when the Academy of Motion Picture Arts and Sciences presented him with a special Academy Award in 1954 .

This collection of films is of extraordinary value to historians. On the one hand, it represents the most reliable primary source of information about the early motion picture that we have. These are the films themselves-not the films as they are described in old catalogues and trade papers. The majority of these films have never been seen by film historians before, and one discovers that all of the previously published film histories have, to a lesser or greater extent, been based, necessarily, upon hearsay and second-hand documentation. The prospect of viewing, for the first time, those films about which we have been writing so knowledgeably for so many years is altogether unnerving.

These are also the most authoritative versions of the early films which still survive. It is the nature of the film-and particularly the silent film-that the length and structure of any production can be altered with relative ease, from print to print. Unhappily, very few of the early films with which historians have previously worked were struck from original negatives. Most of them were duplicated innumerable times, through many printing generations. Not merely has the quality of their images deteriorated, but between an original release print and the print which survives in duped form today, any number of accidental or purposeful alterations may have occurred. In the case of many films, we know that this is so. In the case of others, we assume that it is so. Many a significant film by Méliès, Porter, Griffith, or Ince exists today in several versions, with varying lengths, contents, titles, and order.

If, anywhere in the world, there is a set of prints which we can consider authoritative, it is the set which were filed for copyright purposes in the Library of Congress-the prints which are now available in restored form and which are indexed in this catalogue.

Of course, we know that many copyright prints were filed some time after their production, so that the production and copyright dates cannot be assumed to be coincident. We also 
know that many titles, the prints of which have long since disappeared, were never copyrighted at all. And finally, we assume that in some cases the first release prints of a film may have differed somewhat from the paper-positive print which was filed for copyright.

It seems safe to say, however, that this Library of Congress collection provides the most reliable and authoritative versions of these early films that we shall ever have. As historians, we begin our work with a particular body of material, establish its relative reliability as a primary source of information, and employ it as a standard in authenticating and appraising other research materials. Henceforth, the Library of Congress paper-print collection becomes such a standard.

Not only are these our most reliable prints, but their image quality is far and away the best that is available today. After working for so many years with multi-generation "dupes" of early motion pictures, it is a startling experience for a film historian to see a print which faithfully reproduces the quality of the original. Image details which had long since disappeared in duplicated versions are seen for the first time, and preconceived notions about the "primitive" cinema are hastily revised. In many cases, the quality of the Library's restored prints is equivalent to that of a first-generation release print which might have been struck from the original negative sixty years ago. Even the hand-colored prints have retained much of their original saturation and vividness and are faithfully restored on contemporary color emulsions. Surprisingly, many of the early films in this collection have never been seen on a motion picture screen until now. Scores of films which were produced by the American Mutoscope and Biograph Company were originally printed onto "flip-cards" and were viewed in peep show machines in penny arcades. Mr. Niver has meticulously re-registered each of these films, frame by frame, and we may now see them projected onto a screen, even though their early audiences could not.

Having already given film historians this treasure chest of early motion picture footage, Mr. Niver has now prepared an index of all 3,000 titles which indicates their producers, copyright dates, lengths, contents, distinguishing features, andin many cases-their directors and casts. In doing so, he puts us on notice that each of these films exists, in restored form, in the Library's vaults-not merely authoritative versions of titles with which we were previously familiar, but many scores of films which we have never even seen or heard of before.

Certain consequences-all good-will follow necessarily 
from the publication of this index. First, it is safe to predict that documentary film producers will run, not walk, to the Library's vaults for prints of certain kinds of footage from which compilation productions can profitably be made. Some of these, at least, will be intelligently and lovingly fabricated.

Second, teachers of cinema will, at a reasonable cost, be able to order such prints from the Library of Congress as they require to properly teach the early history of film. On the graduate university research level, there is enough material here to sustain a hundred theses and scores of dissertations.

Finally, a good many histories of the film which concern themselves with the first decades of the art are going to have to be re-written or replaced. Some such texts will require only moderate revision-others, complete overhauls.

In a field of historical research in which a very few people work against very difficult methodological odds, Mr. Niver's contribution looms large indeed. The preparation of this index is as significant a contribution as the restoration of the films which they describe. Together with similar catalogues which are beginning to appear from foreign film archives, it provides us with a substantial research resource for the study of the early international motion picture.

\section{KEY TO MAIN ENTRIES}

Each entry follows an identical pattern. The title is given in bold-face type. The cast, where names have been ascertained, is listed on the next line.

Information on the line after the cast is in this order: producing company; Library of Congress copyright number; date of copyright; length in feet of $16 \mathrm{~mm}$ film; film condition, where this was either "Poor" or "Fair"-all other films being considered "Good."

Categories into which the film has been classified then follow.

The synopsis describes the action or contents of the film, and in some cases indicates significant features of camera position and other technical matters. 